\title{
Pulmonary Calcification in C3H Mice
}

\author{
Midori YOSHIDA, Kazumi UCHIDA, Masami SHIGEMURA, \\ Hiroshi FUJIWARA and Nobuo KUSANO
}

Yakulut Central Institute for Microbiology 1976 Yaho, Kunitachi-shi, Tokyo 186, Japan

(Received 14 November 1984 / Accepted 5 July 1985)

\begin{abstract}
$\mathrm{C} 3 \mathrm{H}$ mice including aged retired breeding females, aged virginal females, young virginal females and young males were examined for the incidence and severity of pulmonary calcification. Pulmonary calcification appeared in aged females, but not in young mice of either sex, and the lesions in aged breeders were more severe and frequent than in aged virgins. These results indicate that spontaneous pulmonary calcification is observed in aged females of the $\mathrm{C} 3 \mathrm{H}$ strain. The findings of increased incidence and severity of pulmonary lesions in aged breeders suggest that pregnancy, delivery and lactation are important enhancing factors. Calcified lesions were also observed in kidney, heart, brain, ovary, choroid plexus, cornea and artery in the animals examined.
\end{abstract}

\section{$\mathrm{C} 3 \mathrm{H}$ 系マウスにおける肺の石灭沈着 \\ 吉田緑・内田和美・重村まさみ \\ 藤原弘・草野信男 \\ ヤクルト本社中央研究所}

乳腺腫瘍好発系として知られる $\mathrm{C} 3 \mathrm{H}$ 系老齢経産マウ スを組織学的に検索したところ，高率に肺の石灰沈着を 認めた。マウスにおける臓器の石灰沈着は心，腎等にお いて報告されているが $[1,2,3,6]$, 本病変の肺における 記載はわずかにEaton ら［1]の報告があるにすぎない。 今回著者らは $\mathrm{C} 3 \mathrm{H}$ 系マウスの肺にみられた石灭沈着の 発生頻度を観察し, 病変の病理学的特徵を検索した。ま た他臓器の石灰沈着の有無についても検索したので併せ 報告する。

動物は老秢経産 $\mathrm{C} 3 \mathrm{H} / \mathrm{HeN}$ マウス, 老齢末経産 $\mathrm{C} 3 \mathrm{H}$ $/ \mathrm{HeN}$ マウス, 若歯末経産 $\mathrm{C} 3 \mathrm{H} / \mathrm{HeN}$ マウス, 若㱓雄 $\mathrm{C} 3 \mathrm{H} / \mathrm{HeJ}$ マウスの計 125 例を用いた。経産マウスは 40 週齢時に 4 産後の動物として購入した。これらの動物
は通常環境下で飼育し，慨，水ともに自由攝取させた。 䬣は長期飼育用の $\mathrm{MF}$ 飼料（オリエンタル酵母）扎よ び MM-3 飼料 (船橋農場), 繁殖用の F-1 飼料 (船橋 農場）を用いた。な掞 F-1 飼料は一部の老柃未経産マ ウスにのみ用いた。動物は殺処分あるいは死亡後剖検 し, 臓器は10\%中性楥衝ホルマリン液で固定した。パラ フィン切片を作製し, ヘマトキシリン・エオジン染色 (H-E染色), コッサ染色, 過ヨウ素酸シッフ反応 (PAS 反応), エラスチカ・ワンギーソン染色を施した。老龄 経産, 老齢未経産, 若秢雄マウスの一部の動物では, OCPC 法 [5]により血清中の Ca 值を測定した。

肉眼的に大部分の老齢マウスでは乳腺腫瘍の発生（81 \%) を認めたが，いずれの臓器にも石灰沈着は認められ 
Table 1. Incidence of pulumonary calcification in aged $\mathrm{C} 3 \mathrm{H}$ mice

\begin{tabular}{ccc}
\hline Age (weeks) & Aged breeder & Aged virgin \\
\hline $40-$ & ${ }^{\text {a) }} 9 / 10^{\text {b) }}(90)^{\mathrm{c})}$ & $1 / 5(20)$ \\
$50-$ & $30 / 33(91)$ & $3 / 9(33)$ \\
$60-$ & $19 / 21(90)$ & $4 / 9(44)$ \\
$70-$ & $6 / 8 \quad(75)$ & \\
\hline Total & $64 / 72 \quad(89)$ & $8 / 23(35)$ \\
\hline
\end{tabular}

a) : No. of mice with calcification

b) : No. of mice examined

c) : Percent (\%)

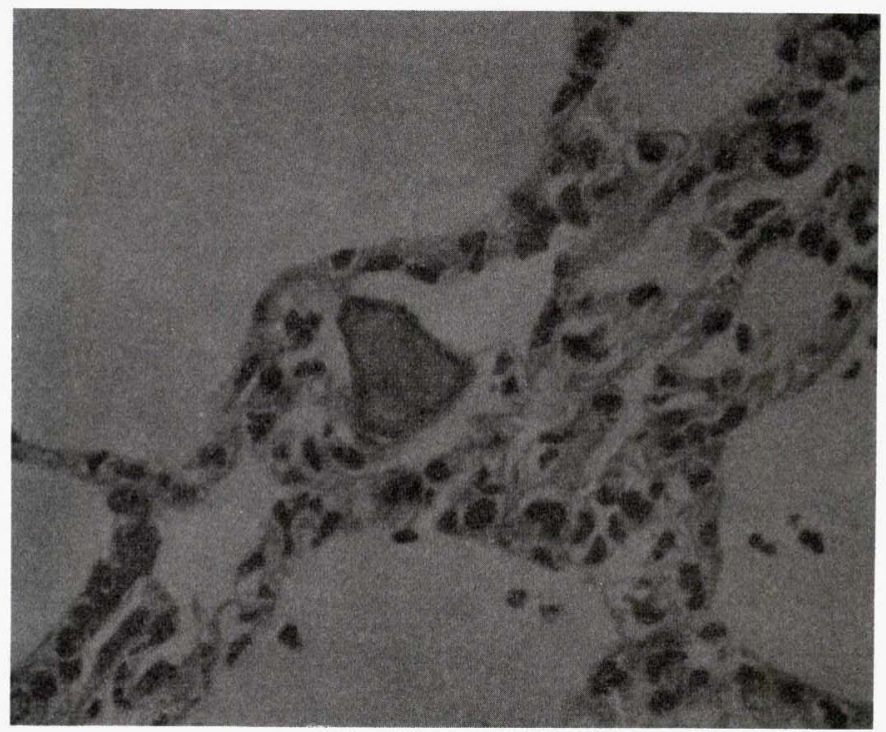

Fig. 1. Lung from aged virgin, mild calcification of alveolar wall, showing deposit resembling a "psammoma body". (H-E. ×600)

\section{なかった。}

組織学的に肺の石灰沈着は老齢経産・未経産マウスで 認められたが (Table 1), 若齢マウスでは認められなか った。本病変は経産マウスで64/72例 (89\%), 未経産マ ウスで8/23例 $(35 \%)$ 出現した。未経産マウスにくらべ 経産マウスの発生頻度は明らかに高く, 病変の程度も高 度であった。しかし，40週齢以後の出現率には加齢によ る変化は認められなかった。また䬣による出現率の差も みられなかった。病変は肺の全葉に分布してみられ, 肺 胞壁に層状の滴状物, いわゆる砂㿔として観察されるこ とが多かったが, 病変の程度が高度な例では肺胞壁にそ
って線状に配列して観察された (Fig. 1)。これらの部 位は, コッサ染色, PAS 反応で陽性を示した。従って 沈着物質は石灰で構成されていると考えられた (Fig. 2)。沈着部位の肺胞壁には, エオジン好性の無定形物質 の肥厚像がみられたが，エラスチカ・ワンギーソン染色 による肺胞中隔の病理像では弾性線維に著変は認められ なかった。

また肺の石灰沈着と乳腺腫瘍の発生との間に関連性は 認められなかった。

今回検索した動物に沶いて, 腎・甲状腺・上皮小体 · 骨に臟器への石灰沈着を起こすような所見は認められな 


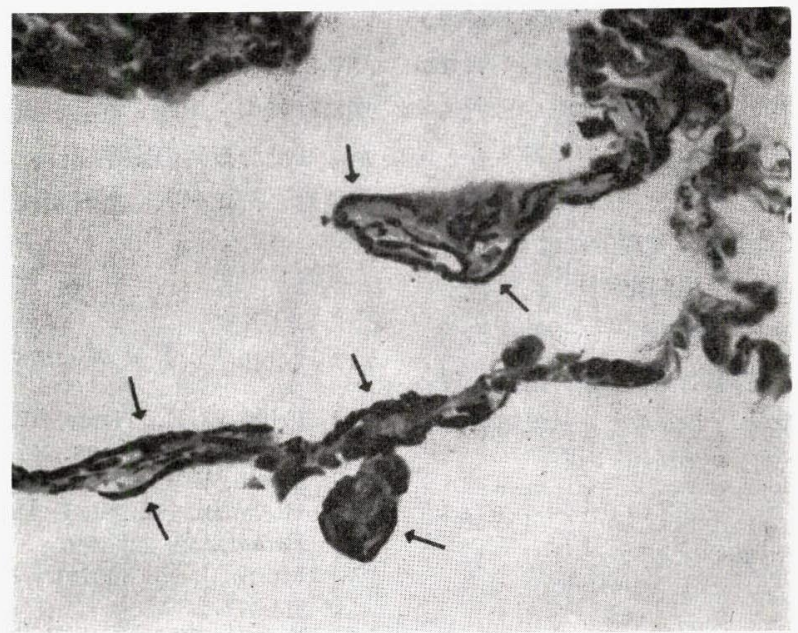

Fig. 2. Lung from aged breeder, severe calcification (arrows), showing calcium deposits linearly along alveolar wall. (von Kossa. ×200)

Table 2. Organs of mice with calcified lesions

\begin{tabular}{lcccc}
\hline & $\begin{array}{c}\text { Aged breeder } \\
(\mathrm{n}=72)\end{array}$ & $\begin{array}{c}\text { Aged virgin } \\
(\mathrm{n}=23)\end{array}$ & $\begin{array}{c}\text { Young virgin } \\
(\mathrm{n}=20)\end{array}$ & $\begin{array}{c}\text { Young male } \\
(\mathrm{n}=10)\end{array}$ \\
\hline \multicolumn{1}{c}{ Age (weeks) } & $58.5 \pm 8.0$ & $52.7 \pm 12.4$ & $8.5 \pm 1.5$ & $10.4 \pm 1.0$ \\
\hline Organ/site & & & & \\
Lung/alveolar wall & $64(89)^{\mathrm{a})}$ & $8(35)$ & 0 & 0 \\
Heart/myocardium & $39(54)$ & $7(30)$ & 0 & 0 \\
Kidney/artery, tubule & $22(31)$ & $3(13)$ & $1(5)$ & 0 \\
Cornea/stroma & $19(26)$ & $1(4)$ & $1(10)^{\mathrm{b})}$ & $1(10)$ \\
Ovary/follicle & $16(22)$ & $2(9)$ & $2(10)^{\mathrm{b})}$ & 0 \\
Choroid plexus/capillary & $6(8)$ & $2(9)$ & 0 & 0 \\
Brain/capillary & $2(3)$ & $11(48)$ & 0 & 0 \\
Artery/tunica media & $1(1)$ & 0 & 0 & 0 \\
\hline
\end{tabular}

a) : Percent (\%), b) : $\mathrm{n}=10$

かった。

肺以外に石灭沈着の観察された臟器は，心・腎・角膜 ・卵巣・脈絡膜・脳または動脈であり,これらの藏器の 主な沈着部位を Table 2 に示した。肺以外の諸藏器の 石灭沈着と肺の石灰沈着の関連性は明らかではなかっ た。

血清中の $\mathrm{Ca}$ 值は老齢マウスでは $10.97 \pm 2.39 \mathrm{mg} / \mathrm{dl}$ であったのに対し，若㱓雄マウスのそれは $9.04 \pm 0.62$ $\mathrm{mg} / \mathrm{dl}$ であり, 老齢マウスの方が若干高い值を示した。 しかし経産・未経産間で血清中の $\mathrm{Ca}$ 值には差がなく,
また個々の動物の $\mathrm{Ca}$ 值と石扊沈着にも相関性はなかっ た。

Eaton らは $\mathrm{C} 3 \mathrm{H}$ 系マウスの自然発生性の石灰沈着に ついて観察し, 肺の石灰沈着は経産マウスで $0.2 \%$ 認め られたと報告している［1］。しかし著者らの検索では本 病変は老秢経産マウスで $89 \%$ と高率に観察されたのみな らず，老齢未経産マウスにも35\%の動物に認められた。 これらの結果より本系統老齢雌マウスには自然発生性の 肺石灰沈着が高率に出現することが明らかになった。

また，本病変の成因については不明であるが，老齢未 
経産マウスにくらべ老龄経産マウスの方が本病変の発生 頻度が高く，しかも病変も高度であったことから本病変 の進展には妊娠・出産・授乳が重要な役割をもつと考え られる。文献的に経産ラットあるいはマウスで腎・心・ 動脈等の石灰沈着が高率に発生するといわれているが肺 については報告されていない $[7.8]$ 。実験的には $\mathrm{C} 3 \mathrm{H}$ 系 マウスをコリン欠乏の低蛋白飼料で長期飼育した場合, 肺を含む全身諸藏器に石灰沈着を起こすという報告があ る [4]。このように肺の石灰沈着には, 妊娠・出産・授 乳・栄養等, 種々の条件が関連していることが推祭され た。

\section{要 約}

$\mathrm{C} 3 \mathrm{H}$ 系老齢経産マウス，老龄未経産マウス，若齢榫 マウス抢よび若㱓雄マウスについて肺の石灰沈省を病理 学的に検索した。この変化は老路経産および老齢未経産 マウスに観察されたが，若㱓マウスには認められなかっ た。病変の発生頻度扰よび程度は経産マウスで高かった。
これらの結果より肺の石灰沈着は， $\mathrm{C} 3 \mathrm{H}$ 系老齢雃 マ ウスに白然発生性に認められる病変であり, 本病変の進 展には妊娠・出産・授乳が重要な役割をもつと考えられ た。また肺以外の臟器では, 腎 ・心 ・卵巣・脳・角膜・ 脈絡膜または動脈にも石灰沈着が認められた。

\section{文献}

[1] Eaton, G. J. et al (1978). Am. J. Pathol., 90, 173186.

[2] Frith, C. H., Haley, T. J., and Seymore, B. W. (1975). Lab. Anim. Sci., 25, 787.

[3] Green, E. U. (1942). Cancer Res., 2, 210-217.

[4] Highman, B., and Dratt, F. S. (1951). Arch. Pathol., 52, 221-229.

[5] Morin, L. G. (1974). Am. J. Clin. Pathol., 61, 114-117.

[6] Nabors, C. E., and Ball, C. R. (1969). Anat. Rec., 164, 153-162.

[7] Reynord, S. (1962). Brit. J. Exp. Pathol., 43, 387391.

[8] Ring, R. W., and Wagner, J. E. (1972). Lab. Anim. Sci., 22, 344-352. 